\title{
NATURAL EFFECT OF MICRONUTRIENT ON GROWTH AND GROWTH PARAMETER
}

\section{OF SESAME OILSEED CROP}

\author{
BARSHA BINDU ROUL ${ }^{1}$, B. K. MISHRA ${ }^{2}$ \& NIBEDITA PRUSTY ${ }^{3}$ \\ ${ }^{1,3}$ SRF-NRRI,Cuttack, Odisa, India \\ ${ }^{2}$ Associate Professor, OUAT, Bhubaneswar, India
}

\begin{abstract}
Micronutrient plays a vital role in the growth of any crop. Due to micronutrient content the oil content may varies. Sesame crop is the queen crop of all oil seed Crop. Here the Researchers were conducting their Experiment in the Year 2014 at Dept. Of Plant Physiology, College of Agriculture, OUAT, Bhubaneswar. Micronutrient application to the crop in various critical stages and growth phases yield a concrete result. A technique was developed for the Farmer Friends by the researchers so that they can able to grow oil seed crops properly.

KEYWORDS: Micronutrient Content, Plant Physiology, \& Oil Seed Crops Properly
\end{abstract}

Received: Sep 14, 2017; Accepted: Oct 01, 2017; Published: Oct 12, 2017; Paper Id.: IJBRDEC20171

\section{INTRODUCTION}

Sesame Crop is an oilseed crop which content rich source of food nutrients having a handsome amount of Oil Content. Micronutrient application may lead to the growth of the nutrient content and oil content of sesame crop. In Odisha condition sesame crop is grown widely as per the demand of Farmers.

Keeping all the above facts into consideration, the present investigation has been undertaken to study the effect of micronutrients applied as foliar spray, on metabolism, growth and yield of sesame crop.

\section{MATERIALSAND METHODS}

Here the researchers were followed Randomized Block Design for conducting this research. A concrete field plan and calendar were strictly followed by the Young Scientists under the supervision of Plant Physiologist, Soil Chemist and Agronomist. Critical care was taken time to time and micronutrient application as per the schedule. 10 replications had been made for getting a concrete result

\section{RESULT AND DISCUSSIONS}

\section{RGR, NAR, CGR and LAD}

- $\quad$ RGR, NAR, CGR and LAD determined between 45 and 60 DAS were depicted in table-7.

- Relative growth rate (RGR) increased with foliar sprays of most of the micronutrients over control, but significant, increase was recorded $\left(101.3 \mathrm{mg} / \mathrm{g} /\right.$ day) in combined micronutrients sprayed ( $\left.\mathrm{T}_{9}\right)$ followed by $\mathrm{Zn}\left(\mathrm{T}_{3}\right)$.

- Net assimilation rate (NAR) significantly influenced by foliar application of micronutrients. The significant increase in NAR over control was observed in case of foliar spray of all the micronutrients 
except Mn $\left(\mathrm{T}_{7}\right)$ which was at par with control. The highest NAR $1.2 \mathrm{mg} / \mathrm{cm}^{2} /$ day was recorded in $\mathrm{T}_{9}$ followed by $\mathrm{B}\left(\mathrm{T}_{2}\right)$ and $\mathrm{Zn}\left(\mathrm{T}_{3}\right)$.

Table.1: Effect of Different Micronutrients on RGR, NAR, CGR and LAD at Different Growth Period

\begin{tabular}{|c|c|c|c|c|}
\hline \multirow[t]{2}{*}{ Treatments } & RGR(mg/gm/Day) & NAR(mg/cm²/Day) & CGR(g/m²/Day) & LAD \\
\hline & 45-60 DAS & 45-60 DAS & 45-60 DAS & 45-60 DAS \\
\hline $\mathrm{T}_{1}$ & 92.5 & 0.87 & 8.7 & 14.97 \\
\hline $\mathrm{T}_{2}$ & 93.2 & 1.13 & 15.9 & 21.49 \\
\hline $\mathrm{T}_{3}$ & 95.0 & 1.05 & 16.6 & 24.31 \\
\hline $\mathrm{T}_{4}$ & 85.2 & 0.95 & 12.9 & 20.66 \\
\hline $\mathrm{T}_{5}$ & 93.5 & 0.91 & 10.5 & 17.37 \\
\hline $\mathrm{T}_{6}$ & 91.2 & 0.96 & 11.4 & 17.90 \\
\hline $\mathrm{T}_{7}$ & 84.4 & 0.85 & 11.4 & 20.24 \\
\hline $\mathrm{T}_{8}$ & 85.5 & 0.98 & 11.3 & 17.36 \\
\hline $\mathrm{T}_{9}$ & 101.3 & 1.20 & 21.1 & 27.01 \\
\hline $\mathrm{T}_{10}$ & 84.4 & 0.91 & 12.2 & 20.36 \\
\hline SE(m) \pm & 0.763 & 0.001 & 0.760 & 0.596 \\
\hline C. D(0.5) & 2.26 & 0.002 & 2.58 & 1.77 \\
\hline
\end{tabular}

Crop growth rate (CGR) was significantly increased by application of different micronutrients as foliar spray. Among the treatments the maximum CGR $21.1 \mathrm{~g} / \mathrm{m}^{2} /$ day was registered in plants applied with combined micronutrients $\left(T_{9}\right)$ followed by $\mathrm{Zn}\left(\mathrm{T}_{3}\right)$, B $\left(\mathrm{T}_{2}\right)$ and Mo $\left(\mathrm{T}_{4}\right)$. The lowest CGR was recorded in control plant $\left(\mathrm{T}_{1}\right)$ where no micronutrient was applied.

Leaf area duration (LAD) was influenced significantly by foliar application of micronutrients. Among the treatments the highest LAD 27.01 was registered in $T_{9}$ followed by application of $\mathrm{Zn}$ (24.31), B (21.49), and Mo (20.66). The lowest LAD was recorded in control plant without micronutrients $\left(T_{1}\right)$.

\section{Chlorophyll Index and Total Chlorophyll Content}

Chlorophyll index and total chlorophyll content of leaf were recorded at 45 and 60 DAS presented in table 8 . The data revealed that, the chlorophyll index and total chlorophyll content of leaf were more at 60 than 45 DAS.

The chlorophyll index differed significantly between the control and micronutrient applied plants. The index variable with the lowest value of $8.16\left(\mathrm{~T}_{1}\right)$ to the high value of $13.39\left(\mathrm{~T}_{9}\right)$ at 45 DAS and lowest value of $8.99\left(\mathrm{~T}_{1}\right)$ to the high value of $17.74\left(\mathrm{~T}_{9}\right)$ at $60 \mathrm{DAS}$ among the treatments. Foliar application of all the micronutrients alone or in combination as well as their commercial mixture significantly increased the chlorophyll index over the control except the application of $\mathrm{Cu}\left(\mathrm{T}_{5}\right)$, which was at par with control. Among the treatments, the highest chlorophyll index was recorded in $\mathrm{T}_{9}$ followed by $\mathrm{Zn}\left(\mathrm{T}_{3}\right), \mathrm{B}\left(\mathrm{T}_{2}\right)$, and Mo $\left(\mathrm{T}_{4}\right)$ at both of the growth stages.

Like chlorophyll index similar trend was also observed for the total chlorophyll content of leaf at both 45 and 60 DAS, which varies with the lowest value of 1.27 and $1.61 \mathrm{mg} / \mathrm{g}$ fresh wt. In $\mathrm{T}_{1}$ and highest value of $1.67 \mathrm{and} 1.93 \mathrm{mg} / \mathrm{g}$ fresh wt. In $T_{9}$ at 45 and 60 DAS respectively. Almost all the treatments of micronutrients showed significantly greater chlorophyll content over the control except the application of $\mathrm{Cu}\left(\mathrm{T}_{5}\right)$ which was found at par with control. Among the treatments, $T_{9}$ showed the maximum chlorophyll content followed by $\mathrm{Zn}\left(\mathrm{T}_{3}\right), \mathrm{B}\left(\mathrm{T}_{2}\right)$ and $\mathrm{Mo}\left(\mathrm{T}_{4}\right)$ at 45 and $60 \mathrm{DAS}$. 
Table 2: Effect of Different Micronutrients on Chlorophyll Index and Total Chlorophyll Content at Different Growth Stages

\begin{tabular}{|l|c|c|c|c|}
\hline \multirow{2}{*}{ Treatments } & \multicolumn{2}{|c|}{ Chlorophyll Index } & \multicolumn{2}{c|}{ Total Chlorophyll Content(mg/g Fresh Weight) } \\
\cline { 2 - 5 } & 45DAS & 60 DAS & 45DAS & 60 DAS \\
\hline $\mathrm{T}_{1}$ & 8.16 & 8.99 & 1.27 & 1.61 \\
\hline $\mathrm{T}_{2}$ & 12.91 & 16.6 & 1.57 & 1.90 \\
\hline $\mathrm{T}_{3}$ & 13.19 & 17.2 & 1.65 & 1.91 \\
\hline $\mathrm{T}_{4}$ & 11.94 & 14.58 & 1.56 & 1.86 \\
\hline $\mathrm{T}_{5}$ & 9.54 & 10.11 & 1.35 & 1.69 \\
\hline $\mathrm{T}_{6}$ & 10.83 & 13.11 & 1.48 & 1.79 \\
\hline $\mathrm{T}_{7}$ & 11.15 & 13.33 & 1.49 & 1.85 \\
\hline $\mathrm{T}_{8}$ & 10.22 & 12.06 & 1.47 & 1.76 \\
\hline $\mathrm{T}_{9}$ & 13.39 & 17.74 & 1.67 & 1.93 \\
\hline $\mathrm{T}_{10}$ & 11.16 & 14.21 & 1.53 & 1.85 \\
\hline $\mathrm{SE}(\mathrm{m}) \pm$ & $\mathbf{0 . 6 5 3}$ & $\mathbf{0 . 5 4 8}$ & $\mathbf{0 . 0 4 7}$ & $\mathbf{0 . 0 0 3}$ \\
\hline $\mathrm{C} . \mathrm{D}(0.5)$ & $\mathbf{1 . 9 3}$ & $\mathbf{1 . 6 2}$ & $\mathbf{0 . 1 4}$ & $\mathbf{0 . 0 0 9}$ \\
\hline
\end{tabular}

\section{CONCLUSIONS}

After going through the various micronutrient treatments to sesame crop, it was concluded that foliar application of different micronutrients either alone or their combination enhanced most of the morpho- physiological traits (plant height, number of branches, capsules per plant, RGR, NAR, CGR and total dry matter accumulation per plant) as well as biochemical attributes (chlorophyll content, N, P and K uptake and oil content), seed yield and yield attributes over control. From the experiment a resultant outcome was observed that micronutrient application leads to vegetative and reproductive growth and enhance the oil content. Hence it may be suggested to the farmer stakeholders and researchers that for oil seed crop micronutrient application should be regularly undertaken

\section{REFERENCES}

1. Ahmad W, Niaz A, Kanwal S, Rahmatullah and Khalid R. 2009. Role of boron in plant growth: a review, Journals of Agricultural Research, 47(3): 329-334.

2. Al-Bamarny SFA, Salman MA and Ibrahim ZR. 2010. Effect of NAA, KNO3 and Fe on some characteristics of leaf and fruit of peach (Prunuspersica L.) cv. early coronet. "World Food System - A Contribution from Europe". Tropentag, September 14 16, 2010 in Zurich

3. Alvarez-Fernandez A, Abadia J and Abadia A. 2006. Iron deficiency, fruit yield and quality. In: Barton LL, Abadia J (eds) Iron nutrition in plants and rizospheric microorganisms. Springer, Dordrecht, The Netherlands: 85-101.

4. Bilen S, Bilen M and Bardhan S. 2011. The effect of boron management on soil microbial population and enzyme activities, African Journal of Biotechnology, 10(27): 5311-5319.

5. Cakmak I, Kalayci M, Ekis H, Brauni J, Kilinc Y and Yilmaz A. 1999. Zn deficiency as a practical problem in Plant and human nutrition in Turkey: a NATO science for stability project, Field Crop Research, 60: 175-188.

6. Cakmak I. 2008. Enrichment of cereal grains with zinc: Agronomic or genetic biofortification, Plant Soil, 302: 1-17.

7. Tiwari RK, Namdeo KN, Girish JA and Jha G. 2000. Effect of nitrogen and sulphur on growth, yield and quality of sesame (Sesamum indicum L.) varieties, Research on Crops, 1: 163-7.

8. Vyakaranahal BS, Shekharagouda M. Patil SA, Prabhakar AS and Giriraj K. 2001. Effects of planting date and chemicals (TIBA and boron) spray on seed yield, its attributes and quality of single and three way cross sunflower hybrids during different seasons, Seed Research, 29: 127-135. 
9. Xiong ZT, Liu C and Geng B. 2006. Phytotoxic effects of copper on nitrogen metabolism and plant growth in Brassica pekinensis Rupr., Ecotoxicology and Environmental Safety, 64: 273-280.

10. Zeidan MS, Hozayn M and Abd El-Salam MEE. 2006. Yield and quality of lentil as affected by micronutrient deficiencies in sandy soils, Journal of Applied Science Research, 2(12): 1342-1345. 